\title{
The motherhood wage gap: What about job amenities?
}

\author{
Christina Felfe * \\ University of St. Gallen, Switzerland
}

\section{A R T I C L E I N F O}

\section{Article history:}

Received 7 May 2009

Received in revised form 23 June 2011

Accepted 26 June 2011

Available online 14 July 2011

\section{JEL Classification:}

J31

J33

Keywords:

Motherhood wage gap

Compensating wage differentials

\begin{abstract}
A B S T R A C T
Women with children tend to earn lower hourly wages than women without children - a shortfall known as the 'motherhood wage gap'. While many studies provide evidence for this empirical fact and explore several hypotheses about its causes, the impact of motherhood on job dimensions other than wages has scarcely been investigated. In order to assess changes in women's jobs around motherhood, I use data from the German Socio-Economic Panel and employ a first difference analysis. The results reveal that women when having children accommodate at their original employer primarily through adjustments in working hours. Yet, when changing the employer women adjust their jobs in several dimensions, such as different aspects of the work schedule (working hours, work at night or according to a flexible schedule) as well as the level of stress. Further analysis provides some limited support for the motherhood wage gap being explained by adjustments in the work conditions.
\end{abstract}

(c) 2011 Elsevier B.V. All rights reserved.

\section{Introduction}

The stylized fact that working mothers tend to earn less than childless women seems to be well established in the economic literature and is called the 'family wage gap' or the 'motherhood wage gap'. Several researchers have found raw motherhood wage gaps of almost $20 \%$ in the US, up to $20 \%$ in Germany and $13 \%$ in the UK. ${ }^{1}$ The following hypotheses about its sources have been investigated: employer discrimination, unobserved heterogeneity between women with and without children, loss in human capital during maternity leave, different work schedules, and choice of sector or job type. Yet so far, the hypothesis that the jobs of women with and without children may differ with respect to certain non-pecuniary characteristics has not been fully explored ${ }^{2}$ : Once having a child,

\footnotetext{
is I am indebted to Libertad Gonzalez for excellent support. I am furthermore thankful to Maia Güell, Sergi Jimenez, Alex Lefter and Ernesto Villanueva for many helpful discussions and to participants at the Applied Lunch Seminar UPF, EALE 2006 and the GSOEP user conference 2006. I gratefully acknowledge the financial support from the Ministry of Education, Spain (Project SEC2005-08793-C04-01). All remaining errors are mine.

* SEW, University of St. Gallen, Varnbüelstr. 14; CH-9000 St. Gallen, Switzerland. E-mail address: christina.felfe@unisg.ch.

${ }^{1}$ See Waldfogel (1997), Harkness and Waldfogel (1999) and Ejrnaes and Kunze (2004).

${ }^{2}$ Existing studies have either looked only at part-time jobs (Waldfogel, 1997; Bratti et al., 2004, health care coverage (Amuedo-Dorantes and Kimmel, 2008) or the public sector (Nielsen et al., 2004) separately. To my knowledge, there exists only one study (Budig and England, 2001) which considers a variety of job characteristics and investigates the possibility that mothers pay a price for enjoying these conditions Nevertheless, the data they have at hand allow them to identify only effects related to occupational changes, but do not enable them to detect any adjustments in specific job features.
}

women might change the criteria according to which they make their job choice. If a better paid job does not offer the desired conditions, a mother may decide to work at a lower paid job with better features. Hence, a mother might sacrifice income to avoid inconvenient job characteristics, referred to as disamenities.

This study extends the existing literature by providing evidence for changes in women's jobs around motherhood, not only with respect to wages but also with respect to non-wage aspects. The focus lies on establishing that, when they have children, women change job characteristics in favorable ways or even change to jobs with more favorable characteristics. A simultaneous drop in wages and jobrelated disamenities is suggestive of a compensating wage differential (CWD) story; i.e. lower wages for mothers might reflect a substitution between income and non-wage job aspects.

The German Socio-Economic Panel represents a particularly suitable dataset for studying the outlined objectives. The dataset provides detailed information about personal attributes, job changes and job characteristics, with attention given to the wage and, particularly, the non-wage aspects of jobs. The longitudinal nature of the data (1984-2007) allows me furthermore to estimate changes in women's jobs once becoming mothers.

In order to allow for comparability with earlier findings, I first establish the magnitude of the family wage gap in my sample. I then analyze changes in dimensions of mothers' jobs which go beyond the much studied wage change. In particular, I allow changes to occur immediately as well as gradually after childbirth. Additionally, I distinguish between changes that occur at the original employer and changes that occur through a change of the employer. All estimations are done using a first difference method. This method does not only allow me to describe adjustments in women's jobs after childbirth, 
but also removes any bias which might arise due to unobserved time constant heterogeneity, for instance in women's earnings ability or preferences for specific job characteristics.

In a second step, I provide some further understanding whether the motherhood wage gap may be (at least partially) explained by a CWD. For this purpose, I analyze the wage gap first for women that neither change their job nor reduce their working hours - the main adjustment mechanism after childbirth - and second for women that do not adjust their job in any of the measured non-pecuniary dimensions. The absence of any difference in wage changes for women giving birth and not giving birth among these subgroups would be a strong argument that changing work conditions play a big role in explaining the wage gap.

In line with the findings of previous studies, women in my sample suffer from a decline in wages when having children $(-10.7 \%)$. In particular, women who remain at the same employer experience a wage drop of $9.3 \%$ and women who change their employer experience a wage drop of even $24.3 \%$. Accommodation at the original employer primarily comes through adjustments in work hours $(-6.6 \mathrm{~h})$. Adjustments involving a change of the employer involve changes in many more dimensions: working hours $(-8.1 \mathrm{~h})$, work at night $(-14.5 \%)$ and according to a flexible schedule $(2.1 \%)$ as well as the level of stress $(-22.7 \%)$. Interestingly, women adjust their jobs mainly upon their return to work after childbirth. Thereafter, we observe, if at all, only a slight reversion of initial changes.

Further analysis provides some limited support for the hypothesis of the family wage gap being explained by a CWD: when restricting the sample to women who stay with the original employer and maintain their work hours, the family wage gap still amounts to $11.2 \%$. Yet, restricting the sample further to women who do not adjust their job in any of the measured non-pecuniary dimension leads to a reduction in the wage gap down to $2.9 \%$. The reduction in the wage gap is, however, not significant at any conventional level.

The remainder of this study is structured as follows. In Section 2, I briefly present previous research on the motherhood wage gap. The underlying theory and methodology are described in Section 3. Section 4 introduces the data and Section 5 reports the estimation results. Section 6 finally concludes.

\section{Background on the motherhood wage gap}

The relation between motherhood and individual wages has been well studied. The motherhood wage gap in the US and UK, according to Waldfogel (1994), is large and persistent. Among young women, mothers' wages lag 20 percentage points behind those of comparable non-mothers. Comparing several industrialized countries, such as Australia, Canada, Germany, Finland and Sweden, Harkness and Waldfogel (1999) find that different institutions lead to a wide variation in the magnitude of the wage gap. On the one hand, a larger family gap is positively correlated with the gender gap, and on the other hand, it is negatively correlated with women's labor market participation.

Several theoretical explanations for the drop in wages around motherhood are offered in the socio-economic literature. The first hypothesis is that women differ with respect to abilities and preferences. Both characteristics may be correlated with fertility and are usually unobserved. Previous studies deal with this issue of unobserved heterogeneity by applying a fixed-effects methodology which removes all permanent differences. Using this approach Waldfogel (1997) cannot detect any unobserved pay-relevant differences between mothers and non-mothers in the US. Anderson et al. (2002), however, find a reduced wage gap of $3.4 \%$ for the first child and 5.6\% for two or more children. Lundberg and Rose (2000) find a wage gap of $9 \%$ even before the first birth. Using German data, Ejrnaes and Kunze (2004) confirm not only the drop in wages after first birth (16.7\%) but also prior to first birth (5\%).
A second hypothesis claims that the presence of children might limit mothers' mobility and hence, restrict mothers in their job choice. Owing to higher job-search costs, mothers might maintain poor job matches; thus, the quality of their job match improves only slowly and lower earnings follow as a consequence. Conversely, Waldfogel (1998a) and Phipps et al. (2001) find that maintaining the same job position after maternity leave decreases the gap. Returning to the same employer acts as an insurance against income loss.

Another possibility is that employers assume differences in productivity and flexibility and thus discriminate against mothers. The hypothesis of discrimination was first suggested by Becker (1985). Discrimination means that given the same individual attributes, employers treat mothers and non-mothers differently for reasons not related to productivity. Employer prejudices could include the idea that mothers are less productive since they have less time and can put less effort into their job. However, it is hard to prove discrimination. Phipps et al. (2001) include the hours spent on unpaid work in their estimation. This approach to testing the discrimination theory reveals that the wage gap declines, but it still remains significant.

Further hypotheses rest upon differences in accumulated human capital. One prominent supposition is that maternity leave interrupts the labor market career and leads, like all kinds of career interruptions, to a loss in work experience and thus to a depreciation of human capital (Mincer and Polachek, 1974). Evidence in support of a decrease in wages due to maternity leave has, for instance, been found for the US and the UK (Waldfogel, 1998b) as well as for Sweden (Albrecht et al., 1999) and Germany (Beblo and Wolf, 2002).

Alongside career interruptions, periods of part-time work also cause depreciation in human capital. Mothers might be particularly likely to take advantage of part-time work since it promotes the combination of work and family. Traditional wage estimations that do not control for part-time periods might underestimate the return to work experience. Recent studies substitute potential work experience with actual work experience, taking into account the duration of nonemployment and part-time spells. Despite the relevance of part-time work for explaining the family gap (Waldfogel, 1997; Joshi et al., 1999; Beblo and Wolf, 2000; Datta Gupta and Smith, 2002), there still exists a family gap for women employed full-time.

Previous studies have related the family gap also to sectoral or occupational segregation. Sectors or types of jobs held primarily by mothers are, in general, lower paid, but might offer a more familyfriendly working environment. This might explain the motherhood wage gap to some degree. Nielsen et al. (2004) address the issue of sector choice. Using a model where the choice between private and public sector is endogenous, they find only a small wage effect of career interruptions in the private sector and no effects in the public one. Amuedo-Dorantes and Kimmel (2008) address the possibility that mothers select into jobs offering employment-based health insurance and find that the wage gap appears to originate, at least in part, from a negative CWD for the presence of health insurance. Accounting for the differences among sectors by matching comparable mothers and non-mothers working for the same firm, Beblo et al. (2009), however, confirm a significant family gap even within firms.

The last two hypotheses address to some extent the focus of this study: once becoming a mother, women might not only earn lower wages, but also enjoy better working conditions and thus, they might sacrifice income to avoid job-related disamenities. Yet, so far, only one study (Budig and England, 2001) has considered a broader range of more detailed job characteristics when investigating the motherhood wage gap. Nevertheless, they rely on average occupational characteristics which prove not only to explain little of the motherhood wage gap, but also do not allow them to shed light on the role of individual adjustments in particular job dimensions.

The present study extends the existing literature in the following ways. First, it provides novel evidence about adjustments in women's jobs when having children using longitudinal data on self-reported 
job aspects. Second, it differentiates between immediate and gradual adjustments. Third, it distinguishes between accommodation at the original employer and accommodation involving a change of the employer. Finally, it sheds some new light on the hypothesis whether the family wage gap may be explained by a CWD story.

\section{Underlying mechanism and methodology}

The idea of the present study relies on the theory of compensating wage differentials (CWD). The theory of CWD, first suggested by Adam Smith (1776) and formalized by Rosen (1986), asserts that jobs are bundles of wages and non-wage aspects and that the loss in one dimension has to be compensated by a gain in the other. Hence, if women once having children experience besides a loss in wages also an improvement in their work conditions, one explanation for the family wage gap may be a CWD.

Previous literature has emphasized that a variety of job features are particularly relevant for mothers (see, for instance, Becker, 1991; Glass and Camarigg, 1992; Del Boca, 2002; DeLeire and Levy, 2004). The first crucial aspect is the working schedule. Given that time becomes a scarce resource for women once having children, we may observe a reduction in the working time. An unconventional working schedule might furthermore not be compatible with the opening hours of childcare institutions. Thus, particular aspects of the working time considered in the subsequent analysis are working hours, work in the evening, at night or according to rotating shifts. The second relevant aspect is a certain degree of flexibility such as flexible working hours or the possibility to work from home. Both features might allow a mother to set her working time as she sees fit and hence to adjust her work to the needs of her children. Besides flexible working hours and work from home, the distance to the workplace as a proxy for commuting time may constitute a high fixed cost of work for mothers. Last, the physical and mental effort required by a job as well as the health risks the worker is exposed to at work may be relevant for a mother since she faces not only double work load but also double responsibility at work and at home. Hence, I additionally evaluate the amount of physical effort a mother has to render and the amount of work-related stress and hazards she has to stand.

There is some empirical evidence that workers receive a monetary premium for an inconvenient schedule and the presence of physical strains (Villanueva, 2007), as well as for work-related stress and dangerous work conditions (Duncan and Holmlund, 1983). Hence, we may expect to observe a financial premium for the above-mentioned job characteristics related to the working schedule - in particular, work in the evening, at night or according to rotating shifts - and the work-related strain - such as physical effort, hazards or stress - but a financial penalty for the ones related to flexibility - such as flexible working hours or the possibility to work from home. Yet, so far, the literature on CWD has not yielded conclusive empirical evidence for the existence of CWD (see Section 3.2 for more details).

\subsection{Estimating the changes in job characteristics}

The main objective of this study is to investigate whether women, when they have children, do not only experience a drop in wages, but also adjust their job in other non-wage aspects. Thus, the aim of the empirical analysis is to relate changes in the number of children to changes in women's jobs, both in monetary as well as in nonmonetary terms.

As pointed out in Section 2, one of the main sources for the motherhood wage gap constitutes unobserved individual differences between mothers and childless women. Women with and without children are for instance likely to differ in their earnings potential or in their preferences for certain jobs. If women with low earnings potential may be more likely to have children, the negative correlation between the presence of children and women's wages might be overestimated. Likewise, women with children may be more likely to opt for a job with better work conditions and hence the coefficients for the presence of children may as well be biased in the non-wage equations. In the case of desired job features, such as flexibility of the work schedule, this would imply an upward bias, while in the case of undesired features, such as physical or mental effort, a downward bias. Yet, taking advantage of longitudinal data and estimating the relationship between "job characteristics" and "number of children" in first differences removes any time-invariant unobserved heterogeneity in terms of ability or preferences. Moreover, using first differences allows me to adequately model adjustments in women's jobs around motherhood. The basic model looks then as follows:

$\Delta \mathrm{Y}_{\mathrm{it}}=\beta_{1}^{*} \operatorname{Birth}_{\mathrm{it}}+\delta^{*} \Delta \mathrm{X}_{\mathrm{it}}+\Delta \mathrm{u}_{\mathrm{it}}$

where $\Delta \mathrm{Y}_{\mathrm{it}}$ represents changes in the hourly wage, as well as changes in several non-wage job aspects, such as working hours, work in the evening, work at night, work according to rotating shifts, flexible work schedule, work from home, commuting distance, job-related stress, physical effort and hazards. Notice that the change variable of "number of children" is "Birth ${ }_{\mathrm{it}}$ ". $\mathrm{X}_{\mathrm{it}}$ comprises a set of control variables which may simultaneously determine a woman's fertility decision and her work-related choices. The selection of these variables is based on the literature on the motherhood wage gap (see Section 2). Thus, $\mathrm{X}_{\mathrm{it}}$ contains not only demographic variables (marital status), but also human capital variables (education, foregone work experience proxied by years out of the labor force and years worked part-time) and a set of sector and year dummies.

In the simplest case where women have children and adjust their jobs immediately after childbirth more or less permanently, $\beta_{1}$ provides us with a reliable estimate for adjustments in women's jobs after childbirth. However, in case mothers change either gradually or only temporarily their work conditions, specification (1) falls short in describing adjustments in women's job situation after childbirth appropriately. Thus, I extend specification (1) as follows:

$\Delta \mathrm{Y}_{\mathrm{it}}=\beta_{1}{ }^{*}$ Birth $_{\mathrm{it}}+\beta_{2}{ }^{*}$ Birth $_{\mathrm{it}-1}+\delta^{*} \Delta \mathrm{X}_{\mathrm{it}}+\Delta \mathrm{u}_{\mathrm{it}}$

where $\beta_{1}$ captures adjustments which occur immediately after childbirth and $\beta_{2}$ captures both gradual changes as well as potential reversion of immediate changes after childbirth.

Finally, to distinguish between accommodation at the original employer and adjustments involving a change of the employer, I include an interaction term between a variable indicating whether a woman starts a new job ("Job Change") and childbirth as well as an interaction term between a variable indicating whether a woman starts a new job and lagged childbirth. Thus the final specification looks as follows:

$$
\begin{aligned}
\Delta \mathrm{Y}_{\mathrm{it}}= & \beta_{1} \text { Birth }_{\mathrm{it}}+\beta_{2} \text { Birth }_{\mathrm{it}-1}+\beta_{3} \text { Birth }_{\mathrm{it}}{ }^{*} \text { Job Change }_{\mathrm{it}} \\
& +\beta_{4} \text { Birth }_{\mathrm{it}-1}{ }^{*} \text { Job Change }_{\mathrm{it}}+\gamma \text { Job Change }_{\mathrm{it}}+\delta \Delta \mathrm{X}_{\mathrm{it}}+\Delta \mathrm{u}_{\mathrm{it}}
\end{aligned}
$$

where $\beta_{1}$ captures accommodations at the original employer which occur immediately after childbirth, $\beta_{2}$ accommodations at the original employer which occur only gradually, $\beta_{1}$ together with $\beta_{3}$ describe immediate adjustments involving a change of the employer and finally $\beta_{2}$ together with $\beta_{4}$ describe gradual adjustments involving a change of the employer.

One major challenge when estimating above described specifications constitutes the fact that most women do not return to work immediately, but only gradually after childbirth. Some women even do not return to work at all. This problem is exacerbated by the institutional setting in Germany: according to the German maternity leave law women have their job guaranteed for up to 3 years after childbirth. In other words, when they have a child, women can stay at 
home for up to 3 years without losing their right to return to their original employer. In the sample of this study, which is described in detail in Section 4, we observe that an enormous percentage of women are working before having children (around 75\%), but only about $25 \%$ are back to work within a year after childbirth, further $20 \%$ return within two years and after three years, which corresponds to the official length of maternity leave, only $65 \%$ of all mothers are working. As a consequence, employing first-differences in its strict sense (i.e. differences between consecutive years), does not capture changes in mothers job characteristics to their full extent, but only for the non-random subsample of women who return to work immediately after childbirth. For this reason, I construct differences between the current year and the last year when a woman was observed to be working (e.g. if the woman is on maternity leave for one year, the difference corresponds to a difference of two years). ${ }^{3}$ As mentioned above, I include "years out of the labor force" as a proxy for foregone work experience. In so doing, I should be able to correct for the problem that the coefficients of the birth variable and the lagged birth variable correspond to changes in job features after career interruptions due to maternity leave of individually varying length.

Finally, I would like to point out that the above described estimation strategy provides us only with valid estimates for the adjustments in working conditions pursued by mothers who are currently working. The estimates cannot be generalized to all mothers, in particular not to mothers who are currently not working - which is the case for around $35 \%$ of all mothers. The reasons for inactivity may be manifold. First, the expected lower wage upon return to work may lie below the reservation wage. Second, once a woman has a baby, her home productivity and thus her reservation wage may rise. If the women who do not return to work are the ones who would suffer the largest wage losses, the uncorrected estimates would underestimate the true wage gap. If the women who do not return to work are the ones with the highest home productivity and also the lowest wage loss, the motherhood wag gap would actually be overestimated. How non-wage aspects interfere in mothers' decisions to return to work is an even more complex question. Yet, so far we lack any theoretical model discussing the consequences for women's non-pecuniary job characteristics, in case they would not have dropped out of the labor force. In light of these difficulties, the current analysis only presents results which are not corrected for selection into work and thus represent only estimates for mothers who are currently employed. ${ }^{4}$

\subsection{Compensating wage differentials}

The second objective of this study is to investigate whether the decline in wages around motherhood might reflect a substitution between income and non-wage job aspects and thus whether the motherhood wage gap may be explained by a CWD.

The measurement of CWD has been discussed extensively in the economic literature. A substantial literature has estimated a hedonic wage regression, a Mincer-type wage regression (Mincer and Polachek, 1974) which includes non-wage aspects of a job as further control variables. ${ }^{5}$ One critique of this first approach to estimate CWD has been its failure to properly control for workers' heterogeneity. Brown (1981) addresses this criticism using panel data, but finds that the coefficients from regressions in levels and regressions using fixed effects are very alike. Similarly, Duncan and Holmlund (1983) estimate a model in first differences and find only significant effects for stress and environmental conditions on wages.

One further critique to the hedonic wage regression is the abstraction from job search and labor market imperfections. Hwang et al. (1998) show theoretically that the standard hedonic wage regression, which ignores the search by employees for better jobs and by firms for more productive employees, yields evidence of CWDs which might be underestimated or even wrongly signed. Moreover, Lang and Majumdar (2004) show that in the presence of frictions on the labor market, the equilibrium job distribution does not need to include CWDs. Hence, when estimating a hedonic wage regression, one might not necessarily find evidence for CWDs, but it is difficult to know if this is due to the fact that the coefficients are biased towards zero or because there are really no CWDs in the labor market.

Given this critique, I pursue a different approach to investigate whether the decline in wages around childbirth may be explained by improvements in working conditions. ${ }^{6}$ In particular, I restrict the sample first to women who do not adjust their jobs with respect to working hours - the main accommodation mechanism - and then to women that do not adjust their jobs in any of the measured nonpecuniary dimensions and estimate the wage change around motherhood using the restricted samples. If there is basically no difference in wage changes around motherhood within these groups, this would serve as a strong argument in favor of the hypothesis that changing work conditions constitute a big part of the family wage gap. However, if the resulting wage changes around motherhood are similar to the wage changes around motherhood observed for all women, this would strongly suggest that, despite changing work conditions, the family wage gap does not reflect a CWD. ${ }^{7}$

\section{Data}

${ }^{3}$ An alternative way to analyze changes in women's working conditions when having children is to concentrate on the changes between working conditions prior to childbirth and after the expiration of official maternity leave period (year four after childbirth). This alternative has, however, several caveats. On the conceptual side, depending on the time when women return to work, they might have already caught up in terms of wages or reversed prior changes in their work conditions. On the more methodological side, it is not obvious how to choose the appropriate sample. First, one would want to restrict the observations to the ones four years after childbirth (otherwise the change variables for "number of children" would also capture the changes between three years prior to childbirth and one year afterwards, etc.). Second, to avoid multiple observations for women without children, one may employ, for instance, a random sampling procedure where only one randomly chosen observation per childless woman is kept in the sample. Results of this approach indicate less remarkable adjustments four year after childbirth than the adjustments reported for the main specification. Nevertheless, four years after childbirth we still observe a simultaneous drop in women's wages $(-8.0 \%)$ and in women's working hours $(-2.3 \mathrm{~h})$ and job-related hazards $(-9.9 \%)$. Moreover, when having changed their jobs during the first three years after childbirth, women tend to jobs with less work in the evening $(-39.2 \%)$. Thus, even if it seems that women have already reversed some of the initial adjustments in their work conditions, we still observe several changes even four years after childbirth. Results are available upon request.

${ }^{4}$ Yet, in an earlier version of this paper (Felfe, 2008) I have additionally estimated the wage regression where I adjust for selection correction using the method suggested by Wooldridge (1995). Estimation results regarding the changes in wages barely alter and are available upon request.
The dataset used is the German Socio-Economic Panel (GSOEP), which is an annually repeated survey of Germans and foreigners in West and East Germany (1984-2007). The longitudinal nature of the data allows me to compare the jobs of women before having a child and once they have one, two or more children. Another feature that makes the GSOEP especially suitable for our purposes is that it provides detailed annual information on pecuniary and non-pecuniary job characteristics.

The particular job features investigated in this study are defined as follows: on the one hand, the wage is included as the logarithm of the

\footnotetext{
${ }^{5}$ See Lucas (1977) for an early application of hedonic wage regressions in the US.

${ }^{6}$ One alternative is to estimate a hedonic wage regression using the sample of jobchangers only. Job turnover is, however, relatively rare. Thus, the resulting sample is very small and the estimates are uninformative. Results are available upon request.

The interpretation of the results using this restricted sample should, however, be taken with caution as we may deal with a special sample of women who may differ in their unobserved characteristics, such as labor productivity, motivation, etc..
} 
Table 1

Summary statistics of the sample.

\begin{tabular}{|c|c|c|c|c|c|c|c|c|}
\hline & \multicolumn{2}{|c|}{ All women } & \multicolumn{2}{|c|}{$\begin{array}{l}\text { Woman observed before } \\
\text { child birth }\end{array}$} & \multicolumn{2}{|c|}{$\begin{array}{l}\text { Woman observed after } \\
\text { child birth }\end{array}$} & \multicolumn{2}{|c|}{$\begin{array}{l}\text { Woman not observed to } \\
\text { have children }\end{array}$} \\
\hline & Overall & Std. dev. & Overall & Std. dev. & Overall & Std. dev. & Overall & Std. dev. \\
\hline Women observed before childbirth & 0.04 & 0.19 & - & - & - & - & - & - \\
\hline Women observed after childbirth & 0.66 & 0.47 & - & - & - & - & - & - \\
\hline Women not observed to have kids & 0.30 & 0.46 & - & - & - & - & - & - \\
\hline Age (in Years) & 33.77 & 7.87 & 26.36 & 4.61 & 36.03 & 7.07 & 29.73 & 7.65 \\
\hline Single & 0.33 & 0.47 & 0.64 & 0.48 & 0.15 & 0.36 & 0.69 & 0.46 \\
\hline Married & 0.56 & 0.50 & 0.31 & 0.46 & 0.72 & 0.45 & 0.24 & 0.43 \\
\hline Separated/divorced & 0.11 & 0.31 & 0.05 & 0.22 & 0.13 & 0.34 & 0.07 & 0.25 \\
\hline Intermediary school degree & 0.62 & 0.49 & 0.69 & 0.46 & 0.61 & 0.49 & 0.62 & 0.49 \\
\hline High school degree & 0.11 & 0.31 & 0.11 & 0.31 & 0.08 & 0.27 & 0.17 & 0.37 \\
\hline University degree & 0.16 & 0.37 & 0.14 & 0.35 & 0.17 & 0.38 & 0.14 & 0.35 \\
\hline Years parttime & 2.52 & 4.09 & 0.55 & 1.56 & 3.38 & 4.51 & 0.90 & 2.40 \\
\hline Out of LF & 1.41 & 2.32 & 0.80 & 1.48 & 1.60 & 2.54 & 1.09 & 1.80 \\
\hline Public sector & 0.36 & 0.48 & 0.37 & 0.48 & 0.38 & 0.49 & 0.32 & 0.47 \\
\hline Service sector & 0.40 & 0.49 & 0.42 & 0.49 & 0.38 & 0.49 & 0.44 & 0.50 \\
\hline Manufacturing & 0.19 & 0.40 & 0.16 & 0.37 & 0.19 & 0.39 & 0.20 & 0.40 \\
\hline Agricultural sector & 0.01 & 0.09 & 0.01 & 0.07 & 0.01 & 0.10 & 0.01 & 0.08 \\
\hline
\end{tabular}

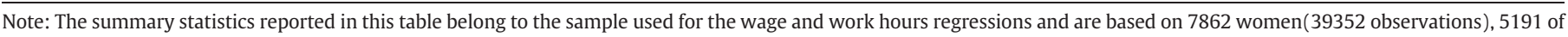
whom are observed to have children prior to 2007 and 2671 of whom are not having children as of 2007.

real gross wage rate ${ }^{8}$; and on the other hand, several dimensions of the non-pecuniary job characteristics such as the aspects of the working schedule (working time measured as agreed hours worked per week as well as working in the evening, at night and according to rotating shifts, the latter ones all being binary variables), the flexibility of the job (flexible working hours and the possibility to work from home, both binary variables, and the distance to the workplace, measured in kilometers) and last the demands of the job (required physical effort, stress and involved hazards, all included as dummy variables).

Before describing the statistical properties of the sample, notice that most job characteristics are only observed for a few years. Shift work and the variables for job demands (stress, physical effort and hazards) are observed for the years 1985, 1987, 1989, 1995 and 2001; work in the evening and during the night only for the years 1990 , 1995 and 2000; only in three years (1997, 1999 and 2002) women were asked if they work from home. In order to maximize the sample size, the following technique is applied to impute these job features. ${ }^{9}$ I use the closest survey prior to childbirth to impute the pre-birth job characteristics and the closest survey after childbirth to impute the post-birth job characteristics. Yet, in case a woman changes her job between the two surveys which provide information about a job characteristic, I can only reasonably impute the adjustments in the job characteristics for the year when the change in employer takes place. The remaining observations between the two surveys are dropped. ${ }^{10}$

The final sample includes all women of fertile age, defined as age 16 to 46 , who are observed to be working in at least two years. The sample, when only restricting to availability of the job characteristics that are included in all surveys (wages and working hours), consists of 7862 individuals ( 39352 observations), 5191 of whom are observed to have children prior to 2007 and 2671 of whom are not having children as of 2007. Notice, however, that sample sizes alter considerably depending on the variable of interest: in case of job distance the

\footnotetext{
${ }^{8}$ The ln of the real gross wage rate is calculated taking the ratio between monthly gross income and monthly contracted working hours. The advantage of taking contracted hours instead of actual working hours is that it is an objective measure and does not create as many outliers. Additionally, I limit the observations of real wage rates to values between the 0.5 th and the 95 th percentile.

${ }^{9}$ Given the structure of the data - basically we observe non-pecuniary job characteristics at most every second year - it is not possible to estimate changes in non-pecuniary job dimensions without relying on imputation. Yet, in a previous version of this paper (Felfe, 2008) I report the results for a fixed effect estimation without imputation of the job characteristics.

${ }^{10}$ In case a woman changes her job several times between two surveys where information about the job characteristic is provided, all observations between these two surveys are dropped.
}

sample is reduced by $53 \%$, in case of rotating shifts, job-related stress, physical effort and hazards by $76 \%$, in case of work in the evening or at night by $83 \%$ and in case of work from home by even $91 \% .{ }^{11}$

Table 1 provides an overview of the summary statistics of the sample used for the wage and work hours regressions. Moreover, it shows a comparison between childless women and women who are observed to have children before and after giving birth. ${ }^{12}$

The first major difference between women before they have children and after they have children is their marital status. While $64 \%$ of the women are still unmarried before being pregnant for the first time, $72 \%$ are married when they have children. Obviously there are also huge age differences: women before pregnancy are younger ( 26 years) than when having children (36 years). Further striking differences, which come along with the age differences, can be observed with respect to work experience: before having children women have interrupted their careers for not even one year, while after having children for almost 2 years. Differences with respect to experience gained in part-time work are even stronger; before having children women have usually worked less than one year in a part-time job (which corresponds to $4 \%$ of their potential work experience), whereas women with children have done so for more than 3 years (which corresponds to $16 \%$ of their potential work experience).

The work conditions and in particular, the comparison of the work conditions of women before and after childbirth provide further interesting evidence (Table 2). The raw differences in mothers' average wages without accounting for differences in the age, education etc., suggest a wage increase after childbirth: the logarithm of real gross wages for women before first pregnancy is 2.3 , while after childbirth it is on average 2.4. The working contracts of women prior to first childbirth include more hours per week than that of mothers ( $37 \mathrm{~h}$ versus $31 \mathrm{~h}$ ). Mothers seem slightly more likely to work according to rotating shifts ( $20 \%$ versus $18 \%$ ), but equally likely to work in the evening (32\% versus 33\%) and less likely to work at night (13\% versus $17 \%$ ). Given the highly regulated German labor market, actually almost no woman enjoys flexible working hours (only $1 \%$ enjoy flexible working hours). Nevertheless, $9 \%$ of all women work from home (12\% do so before motherhood versus $10 \%$ when having

\footnotetext{
${ }^{11}$ In an earlier version of his paper (Felfe, 2008) I employed a different imputation method and restricted the sample to availability of all job characteristics - thus, all wage and non-wage regressions were based on the same sample. Results barely alter and are available upon request.

${ }^{12}$ Summary statistics barely alter across the different samples and are available upon request.
} 
Table 2

Summary statistics for job characteristics.

\begin{tabular}{|c|c|c|c|c|c|c|c|c|c|c|}
\hline & \multicolumn{4}{|c|}{ All women } & \multicolumn{2}{|c|}{$\begin{array}{l}\text { Women observed } \\
\text { before child birth }\end{array}$} & \multicolumn{2}{|c|}{$\begin{array}{l}\text { Women observed } \\
\text { after child birth }\end{array}$} & \multicolumn{2}{|c|}{$\begin{array}{l}\text { Women not observed } \\
\text { to have children }\end{array}$} \\
\hline & Obs. & Ind. & Mean & Std. dev. & Mean & Std. dev. & Mean & Std. dev. & Mean & Std. dev. \\
\hline Ln (real gross wage rate) & 39352 & 7862 & 2.34 & 0.51 & 2.29 & 0.54 & 2.37 & 0.45 & 2.30 & 0.60 \\
\hline Agreed work hours/week & 39352 & 7862 & 33.02 & 9.39 & 37.29 & 5.59 & 30.99 & 10.13 & 36.92 & 6.08 \\
\hline Work in the evening & 6824 & 1755 & 0.33 & 0.47 & 0.33 & 0.47 & 0.32 & 0.47 & 0.37 & 0.48 \\
\hline Night work & 6392 & 1656 & 0.13 & 0.34 & 0.17 & 0.37 & 0.13 & 0.33 & 0.14 & 0.34 \\
\hline Shift work & 9515 & 2424 & 0.19 & 0.39 & 0.18 & 0.38 & 0.20 & 0.40 & 0.17 & 0.37 \\
\hline Stressful job & 9489 & 2422 & 0.75 & 0.43 & 0.75 & 0.43 & 0.74 & 0.44 & 0.78 & 0.41 \\
\hline Physical effort & 9516 & 2421 & 0.38 & 0.49 & 0.38 & 0.49 & 0.41 & 0.49 & 0.34 & 0.47 \\
\hline Hazards & 9501 & 2421 & 0.30 & 0.46 & 0.26 & 0.44 & 0.31 & 0.46 & 0.29 & 0.46 \\
\hline Flexible hours & 39266 & 7853 & 0.01 & 0.08 & 0.01 & 0.08 & 0.01 & 0.08 & 0.01 & 0.08 \\
\hline Work from home & 3582 & 1703 & 0.09 & 0.29 & 0.12 & 0.33 & 0.10 & 0.31 & 0.07 & 0.25 \\
\hline Distance to workplace & 18606 & 4376 & 13.29 & 14.49 & 15.46 & 17.16 & 11.94 & 12.94 & 15.81 & 16.65 \\
\hline Job change & 39352 & 7862 & 0.10 & 0.29 & 0.12 & 0.33 & 0.08 & 0.27 & 0.12 & 0.33 \\
\hline
\end{tabular}

children). Mothers also live slightly closer to their workplace (12 km versus $15 \mathrm{~km})$. Last, there do not seem to be major differences with respect to job-related demands: stress remains rather stables $(74 \%$ versus 75\%), while required physical effort and job-related hazards increase slightly (41\% versus $38 \%$ and $31 \%$ versus $26 \%$, respectively).

\section{Results}

In line with the identification strategy, the presentation of the results is divided into two parts. The purpose of the first part, presented in Section 5.1, is to investigate the changes in women's work environment around motherhood. The second part, presented in Section 5.2, is dedicated to investigating whether the motherhood wage gap might be explained (at least in part) by a CWD. Results are based on OLS estimations, where standard errors are clustered on the individual level.

\subsection{Prevalence of changes in mothers' job characteristics}

For the purpose of comparison with previous studies, I first establish the motherhood wage gap. As we can see in Table 3, Column 1 , the empirical fact of the family wage gap is once again confirmed. When considering observable differences - e.g. differences in women's demographic characteristics, human capital and the sector they are working in - as well as unobservable time constant differences - e.g. differences in women's productivity or career ambitions - the wage gap between women with and without children amounts to $10.7 \%$ (see Table 3 , column 1 ). ${ }^{13}$ Notice that the resulting magnitude of the motherhood wage gap lies slightly below the ones found by previous studies for Germany (e.g. Ejrnaes and Kunze, 2004; Beblo et al., 2009).

To highlight whether adjustments in work conditions happen immediately or gradually, I additionally include a variable indicating lagged birth (see Eq. 2). ${ }^{14}$ As we can see in Table 3, Column 2, the wage loss occurs immediately after maternity leave $(-10.7 \%)$. Interestingly, women's wages start rising again one year after their return to work. To be more precise, the rise in women's wages one year after their return amounts to more than $10 \%$ of the initial decrease $(1.2 \%)$, but is not statistically significant. Thus, it seems that

\footnotetext{
${ }^{13}$ Correctly, the results should be reported as changes in log points. Note, however, that previous studies interpret the coefficients as percentage changes (Anderson et al., 2002; Waldfogel, 1997). As log and percentage points do not differ greatly when talking about small changes, I follow this interpretation.

${ }^{14}$ Given that I employ differences between the current period and the last period the women were observed to be working, the coefficient of the birth variable has to be interpreted as the change in wages experienced by the mother when returning to work after childbirth and analogously, the coefficient of the lagged birth variable as the change in wages one year later (and thus, one year after the end of maternity leave).
}

mothers start catching up in terms of wages already one year after their return to work.

The comparison of a return to the original employer and a return to work which involves a change of employer reveals interesting findings. As we can see in Table 3, Column 3, women, who remain with the original employer after childbirth, experience a slightly smaller wage cut $(-9.3 \%)$. Yet, women, who change employer when having children, suffer from a much stronger decline in wages: when changing the employer immediately after maternity leave mothers

Table 3

The motherhood wage gap.

\begin{tabular}{|c|c|c|c|}
\hline & $\begin{array}{l}\Delta \text { Ln real gross } \\
\text { wage }\end{array}$ & $\begin{array}{l}\Delta \text { Ln real gross } \\
\text { wage }\end{array}$ & $\begin{array}{l}\Delta \text { Ln real gross } \\
\text { wage }\end{array}$ \\
\hline Birth & $\begin{array}{l}-0.107^{* * *} \\
(0.0141)\end{array}$ & $\begin{array}{l}-0.107^{* * *} \\
(0.0141)\end{array}$ & $\begin{array}{l}-0.0925^{* * *} \\
(0.0141)\end{array}$ \\
\hline Birth last period & - & $\begin{array}{l}0.0121 \\
(0.0117)\end{array}$ & $\begin{array}{l}0.0238^{* *} \\
(0.0119)\end{array}$ \\
\hline Birth $*$ Job change & - & - & $\begin{array}{l}-0.150^{* * * *} \\
(0.0566)\end{array}$ \\
\hline Birth last period $*$ job change & - & - & $\begin{array}{l}-0.126^{* *} \\
(0.0525)\end{array}$ \\
\hline Job change & - & - & $\begin{array}{l}0.0587^{* * *} \\
(0.00837)\end{array}$ \\
\hline$\Delta$ Years out of labor force & $\begin{array}{l}-0.0434^{* * *} \\
(0.00299)\end{array}$ & $\begin{array}{l}-0.0439^{* * *} \\
(0.00302)\end{array}$ & $\begin{array}{l}-0.0432^{* * *} \\
(0.00302)\end{array}$ \\
\hline$\Delta$ Years worked part-time & $\begin{array}{l}0.00732 \\
(0.00530)\end{array}$ & $\begin{array}{l}0.00743 \\
(0.00531)\end{array}$ & $\begin{array}{l}0.00776 \\
(0.00531)\end{array}$ \\
\hline$\Delta$ Single & $\begin{array}{l}-0.0178 \\
(0.0121)\end{array}$ & $\begin{array}{l}-0.0178 \\
(0.0121)\end{array}$ & $\begin{array}{l}-0.0175 \\
(0.0121)\end{array}$ \\
\hline$\Delta$ Separated & $\begin{array}{l}0.0138 \\
(0.0122)\end{array}$ & $\begin{array}{l}0.0138 \\
(0.0122)\end{array}$ & $\begin{array}{l}0.0134 \\
(0.0122)\end{array}$ \\
\hline$\Delta$ Intermediary education & $\begin{array}{l}-0.0543^{*} \\
(0.0288)\end{array}$ & $\begin{array}{l}-0.0544^{*} \\
(0.0288)\end{array}$ & $\begin{array}{l}-0.0549^{*} \\
(0.0290)\end{array}$ \\
\hline$\Delta$ High school degree & $\begin{array}{l}-0.148^{* * *} \\
(0.0423)\end{array}$ & $\begin{array}{l}-0.148^{* * *} \\
(0.0423)\end{array}$ & $\begin{array}{l}-0.150^{* * *} \\
(0.0425)\end{array}$ \\
\hline$\Delta$ University degree & $\begin{array}{l}0.217^{* * *} \\
(0.0489)\end{array}$ & $\begin{array}{l}0.218^{* * * *} \\
(0.0489)\end{array}$ & $\begin{array}{l}0.214^{* * *} \\
(0.0491)\end{array}$ \\
\hline$\Delta$ Public sector & $\begin{array}{l}-0.0113^{* *} \\
(0.00547)\end{array}$ & $\begin{array}{l}-0.0111^{* *} \\
(0.00548)\end{array}$ & $\begin{array}{l}-0.00820 \\
(0.00551)\end{array}$ \\
\hline$\Delta$ Service sector & $\begin{array}{l}-0.0176^{* * *} \\
(0.00559)\end{array}$ & $\begin{array}{l}-0.0173^{* * *} \\
(0.00559)\end{array}$ & $\begin{array}{l}-0.0145^{* *} \\
(0.00564)\end{array}$ \\
\hline$\Delta$ Manufacturing sector & $\begin{array}{l}-0.00665 \\
(0.00601)\end{array}$ & $\begin{array}{l}-0.00644 \\
(0.00602)\end{array}$ & $\begin{array}{l}-0.00373 \\
(0.00604)\end{array}$ \\
\hline$\Delta$ Agricultural sector & $\begin{array}{l}-0.0437^{*} \\
(0.0247)\end{array}$ & $\begin{array}{l}-0.0433^{*} \\
(0.0247)\end{array}$ & $\begin{array}{l}-0.0401 \\
(0.0245)\end{array}$ \\
\hline Year dummies & Yes & Yes & Yes \\
\hline Constant & $\begin{array}{l}0.164^{* * * *} \\
(0.0119)\end{array}$ & $\begin{array}{l}0.164^{* * * *} \\
(0.0119)\end{array}$ & $\begin{array}{l}0.140 * * * \\
(0.0126)\end{array}$ \\
\hline Observations & 39352 & 39352 & 39352 \\
\hline Number of individuals & 7862 & 7862 & 7862 \\
\hline R-squared & 0.038 & 0.038 & 0.041 \\
\hline
\end{tabular}

Note: Above's results are based on OLS regression, where standard errors are clustered on the individual level. 
Table 4

Changes in non-wage job features

\begin{tabular}{|c|c|c|c|c|c|c|c|c|c|c|c|}
\hline & $\begin{array}{l}\Delta \text { Ln real gross } \\
\text { wage }\end{array}$ & $\begin{array}{l}\Delta \text { Work } \\
\text { hours }\end{array}$ & $\begin{array}{l}\Delta \text { Work } \\
\text { evening }\end{array}$ & $\begin{array}{l}\Delta \text { Night } \\
\text { work }\end{array}$ & $\begin{array}{l}\Delta \text { Rotating } \\
\text { Shifts }\end{array}$ & $\Delta$ Stress & $\begin{array}{l}\Delta \text { Physical } \\
\text { demands }\end{array}$ & $\Delta$ Hazards & $\begin{array}{l}\Delta \text { Flexible } \\
\text { schedule }\end{array}$ & $\begin{array}{l}\Delta \text { Work from } \\
\text { home }\end{array}$ & $\begin{array}{l}\Delta \text { Distance } \\
\text { to work }\end{array}$ \\
\hline Birth & $\begin{array}{l}-0.0925^{* * *} \\
(0.0141)\end{array}$ & $\begin{array}{l}-6.644^{* * *} \\
(0.349)\end{array}$ & $\begin{array}{l}-0.0756 \\
(0.0476)\end{array}$ & $\begin{array}{l}0.00621 \\
(0.0303)\end{array}$ & $\begin{array}{l}-0.0127 \\
(0.0275)\end{array}$ & $\begin{array}{l}-0.0164 \\
(0.0380)\end{array}$ & $\begin{array}{l}0.0341 \\
(0.0311)\end{array}$ & $\begin{array}{l}0.000884 \\
(0.0352)\end{array}$ & $\begin{array}{l}-0.000468 \\
(0.0028)\end{array}$ & $\begin{array}{l}-0.0112 \\
(0.0703)\end{array}$ & $\begin{array}{l}-0.260 \\
(0.383)\end{array}$ \\
\hline Birth last period & $\begin{array}{l}0.0238^{* *} \\
(0.0119)\end{array}$ & $\begin{array}{l}0.180 \\
(0.264)\end{array}$ & $\begin{array}{l}-0.0088 \\
(0.0419)\end{array}$ & $\begin{array}{l}0.0365 \\
(0.0280)\end{array}$ & $\begin{array}{l}-0.00740 \\
(0.0291)\end{array}$ & $\begin{array}{l}-0.0458 \\
(0.0406)\end{array}$ & $\begin{array}{l}-0.0067 \\
(0.0346)\end{array}$ & $\begin{array}{l}-0.0290 \\
(0.0384)\end{array}$ & $\begin{array}{l}0.0016 \\
(0.00351)\end{array}$ & $\begin{array}{l}0.0127 \\
(0.0649)\end{array}$ & $\begin{array}{l}0.296 \\
(0.384)\end{array}$ \\
\hline Birth* Job change & $\begin{array}{l}-0.150^{* * *} \\
(0.0566)\end{array}$ & $\begin{array}{l}-1.431 \\
(1.229)\end{array}$ & $\begin{array}{l}-0.0334 \\
(0.107)\end{array}$ & $\begin{array}{l}-0.151^{* *} \\
(0.0735)\end{array}$ & $\begin{array}{l}-0.0199 \\
(0.0613)\end{array}$ & $\begin{array}{l}-0.211^{*} \\
(0.114)\end{array}$ & $\begin{array}{l}0.108 \\
(0.0997)\end{array}$ & $\begin{array}{l}0.0436 \\
(0.0827)\end{array}$ & $\begin{array}{l}0.0218^{*} \\
(0.0130)\end{array}$ & $\begin{array}{l}0.0590 \\
(0.0817)\end{array}$ & $\begin{array}{l}1.647 \\
(4.308)\end{array}$ \\
\hline Birth last p. *Job change & $\begin{array}{l}-0.126^{* *} \\
(0.0525)\end{array}$ & $\begin{array}{l}0.954 \\
(0.924)\end{array}$ & $\begin{array}{l}0.0978 \\
(0.113)\end{array}$ & $\begin{array}{l}-0.0418 \\
(0.0917)\end{array}$ & $\begin{array}{l}-0.113 \\
(0.0773)\end{array}$ & $\begin{array}{l}-0.0642 \\
(0.0993)\end{array}$ & $\begin{array}{l}0.121 \\
(0.109)\end{array}$ & $\begin{array}{l}-0.103 \\
(0.0908)\end{array}$ & $\begin{array}{l}-0.0003 \\
(0.0045)\end{array}$ & $\begin{array}{l}0.0650 \\
(0.0877)\end{array}$ & $\begin{array}{l}-4.316 \\
(5.174)\end{array}$ \\
\hline Control variables & Yes & Yes & Yes & Yes & Yes & Yes & Yes & Yes & Yes & Yes & Yes \\
\hline Year dummies & Yes & Yes & Yes & Yes & Yes & Yes & Yes & Yes & Yes & Yes & Yes \\
\hline Constant & $\begin{array}{l}0.140^{* * *} \\
(0.0107)\end{array}$ & $\begin{array}{l}-0.0112 \\
(0.189)\end{array}$ & $\begin{array}{l}-0.0304 \\
(0.0740)\end{array}$ & $\begin{array}{l}-0.0192 \\
(0.0456)\end{array}$ & $\begin{array}{l}0.0127 \\
(0.0402)\end{array}$ & $\begin{array}{l}0.00502 \\
(0.0562)\end{array}$ & $\begin{array}{l}0.0334 \\
(0.0512)\end{array}$ & $\begin{array}{l}0.0509 \\
(0.0539)\end{array}$ & $\begin{array}{l}-0.00309 \\
(0.00335)\end{array}$ & $\begin{array}{l}0.0159 \\
(0.0618)\end{array}$ & $\begin{array}{l}-0.922 \\
(0.845)\end{array}$ \\
\hline Observations & 39352 & 39352 & 6824 & 6392 & 9515 & 9489 & 9516 & 9501 & 39266 & 3582 & 18606 \\
\hline Number of Individuals & 7862 & 7862 & 1755 & 1656 & 2424 & 2422 & 2421 & 2421 & 7853 & 1703 & 4376 \\
\hline R-squared & 0.041 & 0.101 & 0.011 & 0.016 & 0.005 & 0.007 & 0.006 & 0.007 & 0.033 & 0.009 & 0.016 \\
\hline
\end{tabular}

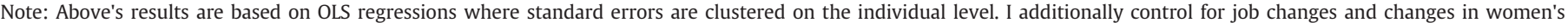
education, marital status and professional sector as well as a set of year dummies.

incur a wage loss of $24.3 \%$. Moreover, while the initial wage loss is slightly reversed when remaining with the original employer $(2.4 \%)$, changing the employer one year after having returned to work leads to a further decrease in wages $(-10.2 \%)$.

The highlighted differences in the motherhood wage gap between women who remain at the original employer and women who change the employer support the hypothesis put forward by Waldfogel (1998a) and Phipps et al. (2001): staying with the same employer after maternity leave acts as an insurance against income loss.

Summarizing the results for the remaining control variables, the signs are as expected: i) career interruptions depreciate human capital and hence, lead to a significant decrease in wages; ii) women's wages rise with education; and iii) women who are working in the service sector seem to experience a wage penalty.

Having established the family wage gap, the next step is to discuss how jobs of women with and without children differ in dimensions other than wages. Table 4 shows the estimates resulting from a first difference analysis, using OLS and clustering standard errors on the individual level, where the dependent variables correspond to the selection of non-wage job aspects introduced in Section 4. Again I distinguish between immediate and gradual adjustments in women's working conditions after childbirth as well as between accommodations at the original employer and adjustments involving a change of employer.

Accommodation at the original employer comes mainly through a reduction in working hours $(-6.6 \mathrm{~h})$. All further dimensions of the work schedule are unchanged upon the return to work after childbirth. Similarly, there are no adjustments observed in any other dimensions of women's work, such as job related stress, effort or hazards. Moreover, despite the regeneration of wages observed one year after the return to work, we do not observe any adjustments in women's jobs one year after the end of maternity leave when staying with the same employer. Thus, when they stay with their original employer, women seem to mainly bargain, if at all, about a reduction in working hours, not, however, about an adjustment in other aspects of the work schedule or the conditions of the job.

Quite the opposite is true for women who change the employer: these women experience changes in several measured dimensions. ${ }^{15}$ Particularly striking adjustments are observed with respect to the working schedule. First of all, we can see a strong and significant decrease in working hours as soon as children are present. The

\footnotetext{
15 Notice, after each regression I have conducted a $t$-test testing for joint significance of the coefficients "birth" and "birth* job change". If not indicated otherwise, the null hypothesis of the two coefficients being equal to zero could be rejected (at least) at the $5 \%$ significance level.
}

reduction in working hours amounts to $8.1 \mathrm{~h}$. In addition, mothers seem to sort into jobs where they are less likely to work during inconvenient hours, such as during the night $(-14.5 \%)$. Moreover, when they change employer, mothers seem to enjoy a more flexible working schedule (2.1\%). Finally, after a job change mothers are working in an environment which exposes them to a lower level of stress ( $-22.7 \%)$. Interestingly, a change of the employer which occurs later, in particular one year after the end of maternity leave, does not lead to any major adjustment.

Finally, I would like to give consideration to the findings of previous studies who detected a stronger decline in wages after the birth of a second or a further child than after the birth of the first child (e.g. Anderson et al., 2002). For this reason, I would like to discuss briefly the findings when further distinguishing between first birth and second or later births. ${ }^{16}$ In contrast to the findings of previous studies, I do not find any additional loss in wages after the birth of a second child. Nevertheless, in both cases, after the birth of the first or the second child, women when remaining at their original employer accommodate mainly through a reduction in working hours. Major adjustments after childbirth, independently if it is the birth of a first, second or further child, only occur when changing the employer.

Taken together, the findings of this section allow already for a first consistency check of the hypothesis that women might substitute wages for non-wage job aspects. The fact that women who change employer after childbirth do not only incur a much more pronounced wage loss than women who remain at the original employer, but also experience adjustments in many more dimensions, may point to a CWD story. In other words, the prevalence of a more flexible working schedule, such as a shorter working week, less work during the night, more flexible working hours, as well as a lower level of stress may require a certain price that mothers have to pay when adjusting their jobs in these dimensions. As a consequence, the motherhood wage gap may be explained by a substitution between wages and non-wage aspects. Nevertheless, I cannot exclude the possibility that the greater wage gap for job changers is also related to a loss in firm specific human capital. For this reason, the succeeding section sheds some more light on the hypothesis of the family wage gap being explained by a CWD.

\subsection{The motherhood wage gap - a compensating wage differential?}

The remaining step is to investigate further upon the outlined hypothesis whether the motherhood wage gap might be explained by

\footnotetext{
16 Results are available upon request.
} 
a CWD. As described above, women who remain with the original employer experience a much less pronounced wage drop than women who change the employer upon return to work after childbirth $(9.3 \%$ versus $24.3 \%$ ). Moreover, accommodation at the original employer mainly occurs through reduction in working hours, while accommodation involving a change of employer involves adjustments in many more dimensions. Having these results in mind, it might be worth to investigate further upon a potential trade-off between wages and non-wage job aspects.

As explained in Section 3.2, one approach to see whether the remaining family wage gap may be explained by a CWD story is to study the wage change among women who only partially adjust their job or even do not adjust their job in any of the measured nonpecuniary dimensions. If there are no differences in wage changes around motherhood among these selected groups, there exists a strong argument in favor of the hypothesis that changing work conditions constitute a big part of the motherhood wage gap. Yet, if there are differences in wage changes related to motherhood among these groups, the motherhood wage gap might not (exclusively) reflect changing work conditions.

One caveat when pursuing this strategy is that the non-pecuniary job characteristics are only included in selected surveys. As a consequence restricting the sample to availability of all job characteristics and moreover to no adjustments in any of the job characteristics leads to a severe reduction in sample size. ${ }^{17}$ For this reason, I pursue the following steps to test whether adjustments in nonpecuniary job dimensions might help to explain the existence of the family wage gap. First, I restrict the sample to women who remain at their original employer and do not reduce their working hours (in this case the sample is reduced from 39352 observations/7862 women to 20879 observations/6075 women). The underlying idea is to exclude the main mechanism through which women accommodate at their original employer when returning to work after maternity leave. Second, I restrict the sample further to observations where I possess information on all job dimensions. This step allows me to compare the motherhood wage gap across the two samples - with and without information on all job characteristics when conditioning on no job change and no adjustment in working hours (20879 versus 280 observations or put it differently, 6075 versus 172 women). Finally, I exclude all women who are observed to adjust their job in any of the measured non-pecuniary job characteristics (44 observations/34 women).

Table 5 shows the results of the wage regression, where I distinguish between immediate and gradual changes, using the different samples. Column 1 of Table 5 displays above findings for the decline in wages around motherhood using the full sample: it amounts to $10.7 \%$. Column 2 of Table 5 displays the results when using the subsample of women who do not switch job nor reduce their working hours: the difference in the wage gains between women with and without children amounts to $11.9 \%$ (and is not statistically different from the wage gap estimated using the full sample). This result confirms the finding of previous studies: the prevalence of parttime cannot explain the remaining family wage gap (Waldfogel, 1997; Joshi et al., 1999; Beblo and Wolf, 2000; Datta Gupta and Smith, 2002).

Interestingly, despite the dramatic loss in observations when conditioning the sample on availability of all non-pecuniary job characteristics, the estimated family wage gap barely alters: $11.9 \%$ versus 11.2\% (see Column 2 and Column 3, Table 5). This seems to suggest that the main pattern of the results is not driven by the composition of the sample. However, the reduction in sample size leads to a loss in precision: the standard error is more than three times bigger.

\footnotetext{
17 To be more precise, we can rely on only two survey years when requiring information on all dimensions of mothers' jobs.
}

Table 5

Wage gap for women without adjustment in their working conditions.

\begin{tabular}{|c|c|c|c|c|}
\hline & (1) & (2) & (3) & (4) \\
\hline & $\begin{array}{l}\Delta \text { Ln real } \\
\text { gross wage }\end{array}$ & $\begin{array}{l}\Delta \mathrm{Ln} \text { real } \\
\text { gross wage }\end{array}$ & $\begin{array}{l}\Delta \mathrm{Ln} \text { real } \\
\text { gross wage }\end{array}$ & $\begin{array}{l}\Delta \text { Ln real } \\
\text { gross wage }\end{array}$ \\
\hline Child & $\begin{array}{l}-0.107^{* * *} \\
(0.014)\end{array}$ & $\begin{array}{l}-0.119^{* * *} \\
(0.020)\end{array}$ & $\begin{array}{l}-0.112^{*} \\
(0.065)\end{array}$ & $\begin{array}{l}-0.029 \\
(0.048)\end{array}$ \\
\hline Child lagged & $\begin{array}{l}0.012 \\
(0.012)\end{array}$ & $\begin{array}{l}0.0117 \\
(0.012)\end{array}$ & $\begin{array}{l}0.020 \\
(0.131)\end{array}$ & $\begin{array}{l}- \\
-\end{array}$ \\
\hline Control variables & Yes & Yes & Yes & Yes \\
\hline Observations & 39352 & 20879 & 280 & 44 \\
\hline Number of individuals & 7862 & 6075 & 172 & 34 \\
\hline R-squared & 0.038 & 0.056 & 0.038 & 0.067 \\
\hline
\end{tabular}

Note: Above's results are based on OLS regressions where standard errors are clustered on the individual level. I additionally control for changes in women's education, marital status and professional sector as well as a set of year dummies.

Column (1): full sample.

Column (2): restricting the sample to job stayers who do not adjust their working hours. Column (3): restricting the sample furthermore to availability of all job characteristics. Column (4): restricting the sample furthermore to no adjustment in any of the work conditions.

When restricting the sample further to women who do not adjust their job in any of the measured non-pecuniary dimensions, the motherhood wage gap goes down to $2.9 \%$. Notice that despite of the sample reduction (by $84 \%$ ) the standard error does not further increase. Nevertheless, the resulting estimate is rather imprecise: the $95 \%$ confidence interval reaches from $-12.7 \%$ to $7.0 \%$, which contains the point estimate of the overall family wage gap.

The latter result provides some limited support for the motherhood wage gap being explained by adjustments in work conditions which so far have been mainly neglected by the literature on the motherhood wage gap: different aspects of the work schedule (work in the evening, at night, according to rotating shifts or flexible working hours) or job-related strains such as the level of stress, physical effort or hazards. This interpretation should, however, be taken with caution as we deal with a rather small as well potentially selected sample of women who may differ in their unobserved characteristics, such as labor productivity or motivation.

\section{Conclusion}

The balance of career and family is a hot topic on the current political agenda. One indication that mothers still encounter barriers to success in the labor market is the family wage gap - i.e. the fact that mothers earn lower wages than childless women. Even if several hypotheses about its sources have been explored, much of the gap remains unexplained.

This study contributes to the literature by putting forward the supposition that the motherhood wage gap can be attributed to a compensating wage differential (CWD) story. For this purpose, I investigate not only changes in wages, but also changes in several non-wage aspects of women's jobs once they become mothers.

Data from the German Socio-Economic Panel (GSOEP) are used to estimate the changes in women's work conditions once they have children. I employ a first difference analysis, which allows me to describe adjustments in women's jobs while considering unobserved individual heterogeneity, such as career ambition or earnings potential. I additionally distinguish between immediate and gradual adjustments in women's work environment when having a child, as well as between accommodation at the original employer and adjustments involving a change of the employer.

The wage gap between women with and without children reaches $9.3 \%$ in case they remain at the original employer and $24.3 \%$ in case they change their employer. This differential magnitude in the wage gap is reflected in differential adjustments in further non-wage aspects. While accommodation at the original employer mainly occurs 
through adjustments in working hours $(-6.6 \mathrm{~h})$, adjustments involving a change of the employer involve adjustments in several dimensions: work hours $(-8.1 \mathrm{~h})$, work at night $(-14.5 \%)$, work according to a flexible schedule (2.1\%), and finally the level of stress $(-22.7 \%)$. Interestingly, adjustments in women's work environment occur mainly immediately when returning to work after maternity leave. Changes which occur later reflect if anything only a slight reversion of initial adjustments.

Yet, despite substantial adjustments in women's jobs when having children, I find only limited support for a trade-off between wages and non-wage aspects after childbirth. The family wage gap of women who neither change jobs nor reduce their working hours - the main mechanism through which women accommodate at their original employer - amounts still to $11.9 \%$. Restricting the sample to women who do not adjust their job in any non-pecuniary dimension reduces the estimated wage gap to $2.9 \%$. Due to a rather small and potentially selected sample, the interpretation of this result should, however, be taken with caution and only considered as limited evidence for the family wage gap being explained by a CWD story.

\section{References}

Albrecht, J., Edin, P., Sundström, M., Vroman, S., 1999. Career interruptions and subsequent wages: a reexamination using Swedish Data. Journal of Human Resources 34 (2), 294-311.

Amuedo-Dorantes, C., Kimmel, J., 2008. New Evidence on the Motherhood Wage Gap. IZA Discussion Paper No.3662.

Anderson, D., Binder, M., Krause, K., 2002. The motherhood wage penalty: which mothers pay it and why? The American Economic Review 92 (2), 354-358.

Beblo, M., Wolf, E., 2000. "How Much Does a Year off Cost? Estimating the Wage Effects of Employment Breaks and Part-Time Periods"; DP 00-69. ZEW.

Beblo, M., Wolf, E., 2002. "Wage Penalties for Career Interruptions"; DP 02-45. ZEW.

Beblo, M., Bender, S., Wolf, E., 2009. Establishment-level wage effects of entering motherhood. Oxford Economic Papers 61 (S1), 11-34.

Becker, G., 1985. Human capital, effort, and the sexual division of labor. Journal of Labor Economics 3 (1), S34-S58 pt.2:

Becker, G., 1991. "A Treatise on the Family”; Cambridge. Harvard University Press, MA.

Bratti, M., Del Bono, E., Vuri, D., 2004. New mothers' labour force participation in Italy: the role of job characteristics. Labour 19, 79-121 s1).

Brown, C., 1981. Equalizing differences in the labor market. Quarterly Journal of Economics 94 (1), 113-134

Budig, M., England, P., 2001. The wage penalty for motherhood. American Sociological Review 66 (2), 204-225.

Datta Gupta, N., Smith, N., 2002. Children and career interruptions: the family gap in Denmark. Economica 69, 609-629.
Del Boca, D., 2002. The effect of child care on participation and fertility. Journal of Population Economics 15 (3).

DeLeire, T., Levy, H., 2004. Worker sorting and the risk of death on the job. Journal of Labor Economics 22 (4), 925-954.

Duncan and Holmlund, 1983. Was Adam Smith right after all: another test of the theory of compensating wage differentials. Journal of Labour Economics 1 (4), 366-379.

Ejrnaes, M., Kunze, A., 2004. Wage dips and drops around first birth. CAM Working Paper 2004-01.

Felfe, C., 2008. The child penalty - what about job amenities? University of St. Gallen, Department of Economics, DP No. 2008-22.

Glass, J., Camarigg, V., 1992. Gender, parenthood and job-family compatibility. The American Journal of Sociology 98

Harkness, S., Waldfogel, J., 1999. The family gap: evidence from seven industrialized countries. CASE paper no.29 Centre for Analysis of Social Exclusion, London.

Hwang, H., Mortensen, D., Reed, W.R., 1998. Hedonic wages and labor market search. Journal of Labor Economics 16 (4), 815-847.

Joshi, H., Paci, P., Waldfogel, J., 1999. The wages of motherhood: better or worse? Cambridge Journal of Economics 23 (5), 543-564.

Lang, K., Majumdar, S., 2004. The pricing of job characteristics when markets do not clear: theory and policy implications. International Economic Review 45, 1111-1128.

Lucas, R., 1977. Hedonic wage equations and psychic wages in the returns to schooling. The American Economic Review 67 (4), 549-558.

Lundberg, S., Rose, E., 2000. Parenthood and the earnings of married men and women. Labour Economics 7 (6), 689-710.

Mincer, J., Polachek, S., 1974. Family investment in human capital: earnings of women. Journal of Political Economy 82 (s2), S76-S108

Nielsen, H., Simonsen, M., Verner, M., 2004. Does the gap in family-friendly policies drive the family gap? The Scandinavian Journal of Economics 106 (4), 721-744.

Phipps, S., Burton, P., Lethbridge, L., 2001. In and out of labour market: long-term income consequences of child-related interruptions to women's paid work. Canadian Journal of Economics 34 (2), 411-429.

Rosen, H., 1986. The theory of equalizing differences. In: Ashenfelter, O., Layard., R. (Eds.), Handbook of Labor Economics, Vol. 1. Elsevier, Amsterdam.

Smith, A., 1776. An Inquiry into the Nature and Causes of the Wealth of Nations. The University of Chicago Press, Chicago. 60637; Edition 1976.

Villanueva, E., 2007. Estimating compensating wage differentials using voluntary job changes: evidence from Germany. Industrial \& Labor Relations Review 60 (4).

Waldfogel, J., 1994. Women working for less. Family status and women's pay in the US and UK. Working Paper \#D-94-1, Malcom Wiener Center for Social Policy, Cambridge.

Waldfogel, J., 1997. The effect of children on women's wages. American Sociological Review 62, 209-217.

Waldfogel, J., 1998b. Understanding the family gap in pay for women with children. Journal of Economic Perspectives 12

Waldfogel, J., 1998a. The family gap for young women in the US and GB: can maternity leave make a difference? Journal of Labour Economics 16 (3), 505-545.

Wooldridge, J., 1995. Selection corrections for panel data models under conditional mean independence assumptions. Journal of Econometrics 68, 115-132. 